\title{
The Lexicons of Early Modern News
}

\author{
Paul Arblaster, André Belo, Carmen Espejo, Stéphane Haffemayer, \\ Mario Infelise, Noah Moxham, Joad Raymond and Nikolaus Schobesberger
}

The vocabulary for news spread across Europe with the news itself. This is evident enough in the geographical dispersal of words including gazette, avviso, mercury. However, also like the news itself, as these words were domesticated into regional languages and local news cultures they developed local inflections. Looking closely at the languages of news across Europe reveals continuities and discontinuities in practice, it identifies the movement of conventions and uncovers false friends that are evidence of both common and idiosyncratic practices.

One of the first things discovered in the workshops organised by the Leverhulme-Trust funded research network, News Networks in Early Modern Europe 1500-1700, was that we needed to understand more precisely the lexicons we deployed in various tongues in a wider context, and that a polyglot lexicon was a necessary foundation for a transnational understanding of the cosmopolitan cultures of European news. The history of news in early modern Europe has been strongly shaped by-and consequently fashioned into — national narratives, narratives that risk ignoring or downplaying the extent to which news and its circulation were transnational phenomena. It was a starting point of the network and its participants that the tendency to view the historiography of news in national isolation, by separating news products from the variety of forms, names and networks by which they were distributed across Europe, risks simplifying news history into a narrowly developmental account that measures the sophistication and interest of a given news culture principally by the speed with which it brought about the printed daily newspaper. We sought to replace this with an international story, recognising the international character and freedom of movement of news, its fungibility and mobility between diverse political, social, and linguistic contexts.

Translation (and thus communities of jobbing translators) was one of the foundations of the movement of news, and it was soon apparent to the network that the polyglot and cosmopolitan character of Europe's vocabularies of news presented unanticipated challenges. Discussions of forms, networks, and definitions of news in the course of the project's researches highlighted a number of important questions: how can we be sure, when we use a single word to

(C) PAUl ARBLASTER ET AL., 2016 | DOI 10.1163/9789004277199_004

This is an open access chapter distributed under the terms of the Creative Commons Attribution-

Noncommercial-NoDerivatives 3.o.Unported (CC-BY-NC-ND 3.0) License 
compare news publications, that we are talking about similar phenomena? Are the various names given to printed and manuscript forms of news commensurate between countries? Conversely, how is a given word used as it moves between vernaculars? How was the terminology understood, and how was the contemporary sense of those meanings recorded? What degree of influence or feedback was there between national news cultures?

Names for news items and news objects moved alongside the things themselves; words imperfectly described things, and they adapted to local and regional contexts; and their meanings changed according both to the exigencies of varying circumstances and to changing cultural contexts. For instance, as is shown below, part of the expansion of the active vocabulary of news in English was to include the use of such words as proceedings, affairs, occurrences, transactions, and passages in the titles of news publications (all of which seem to reflect the importance of reporting on parliamentary activity to the news culture of the 1640s). Yet if these titles are suggestive of a specifically English aspect to that culture, there were also numerous titles of early English news publications-mercuries, corantoes, gazettes, tidings-which borrowed from the continental vocabulary in a manner that suggests that the foreignness of the contents, forms and titles of news publications was part of what made them recognisable as news. It is also worth noticing that this foreignness was generic: that is, the foreign term by which the news was recognised need not originate in the same place as the news it contained. This article records numerous instances of terms adopted from the immediate example of a neighbouring region, which had itself borrowed the term from elsewhere.

This chapter began life as a multi-way dialogue or polylogue, and developed into a collaborative reference essay. In it we provide a non-exhaustive yet panoptic survey of the rapidly-changing lexicons of news terminology in seven of early modern Europe's vernaculars-Dutch, English, French, German, Italian, Portuguese, and Spanish - covering the period from the early sixteenth to the beginning of the eighteenth century. It is our hope that scholars and students of the history of news will find this useful, not simply because it brings this information together in one place for the first time, but also because it broadens our understanding of the interrelatedness of early modern news genres, and assembles an important strand of evidence in drawing the historical and geographical outlines of a European news network. It underscores the necessity of studying the European news network as a whole. It further provides a practical foundation for many of the analyses of transnational flows that appear elsewhere in this volume.

Although we have sought to avoid falsely isolating national cultures of news, the logic of a survey of early modern news terminology seems to us to require 
separate treatment for each language considered; and, in order that the migration of forms and terms may be more readily apparent, the discussions of each language have been arranged according to a rough chronology of innovation (beginning with the establishment of avvisi networks in Italy, to the appearance of printed news pamphlets and the first newspapers in the Holy Roman Empire, the establishment of Dutch-language couranten and nieuwe tijdinghen, moving on to France, England, Spain and Portugal.)

A note on typography: in order to avoid privileging one news vocabulary over others, the convention by which non-English words are italicised within English prose has been abandoned. Terms whose meaning and usage are the subjects of this essay's scrutiny are given in bold where they are first encountered (or reintroduced to discussion), and are thereafter not emphasised. Italics are confined to titles of printed works; a word which is both italicised and bold denotes an instance where the title of a particular printed work introduces a term which comes to be used generically.

\section{Italy}

The word nuova (singular; the plural is nuove; and variants include nova, nove, novella) has been used since at least the fifteenth century to indicate the account of something that has happened recently. It shares its meaning with the English news.

Over the same period avviso has been a generic term: it does not distinguish between the object (a sheet containing written news) and its content (the news). An avviso could be a news-sheet containing various news items, or it could equally well be a single piece of news. ${ }^{1}$ The avviso (handwritten or printed) became the principal vehicle of news communication on the Italian peninsula, and continued to predominate until the end of the eighteenth century. Its origins can be traced to the last decades of the fourteenth century, when the particularly informative parts of private and merchants' letters or of political

1 On the Italian terms see Mario Infelise, Prima dei giornali. Alle origini della pubblica informazione (secoli XVI e XVII) (Rome and Bari: Laterza, 2002), and 'From merchants' letters to handwritten political avvisi: notes on the origins of public information', in Cultural Exchange in Early Modern Europe, vol. 3, Correspondence and Cultural Exchange in Europe 1400-1700, ed. Francisco Bethencourt and Florike Egmond (Cambridge: Cambridge University Press, 2007), pp. 33-52. Also still useful is Salvatore Bongi, 'Le prime gazzette in Italia', Nuova Antologia, 1 (1869), pp. 311-46. On Avviso see also the studies of Johann Petitjean, 'Mots et pratiques de l'information. Ce que aviser veut dire (Xvie-Xviıe siècles)', Mélanges de l'École française de Rome -Italie et Méditerranée, 122.1 (2010), pp. 107-21, and L'intelligence des choses. Une histoire de l'information entre l'Italie et Mediterranée (Rome: École Française de Rome, 2013), pp. 2-5. 
dispatches began to be excerpted and incorporated into a single sheet with other, similar excerpts. The result was a text made up of short informative sections, relaying news that was thought to be of general interest. Between the end of the fifteenth and the beginning of the sixteenth century the layout of the avviso was gradually perfected. The news was introduced by headlines such as "Copia di nuove in lettere da ..." (copy of news in letters from ...), "Sommario di avvisi" (summary of avvisos), "Sommario di nove" (summary of news), and so on. ${ }^{2}$

In Venice the term reporto (also riporto/raporto) had the same meaning as avviso. They were used interchangeably, even if later on, in the eighteenth century, reporto could also indicate a single item of information. The avvisi or reporti (plural) were usually anonymous, although it is possible to find them signed, especially when they were addressed to important personalities. Some began to be issued in serial form from the second half of the fifteenth century, and in periodical form from about 1550 . Both were commonly used in the papal bulls against the news circulation between 1572 and $1590 .{ }^{3}$ The same meaning was conveyed by the word ragguaglio (plural ragguagli), less used, less common, but employed by the writer Trajano Boccalini in the title of his famous book De' ragguagli di Parnaso (Venice, 1612), translated into English as Advertisements from Parnassus by Henry Carey, Earl of Monmouth (London, 1656). ${ }^{4}$

Another important distinction was between avvisi secreti (secret avvisos), carrying confidential information addressed to men of power, and avvisi pubblici (public avvisos). The former were exclusively handwritten, while the latter might be handwritten or printed. ${ }^{5}$

The gazzetta was the avviso pubblico par excellence. It was an avviso available to anyone who could afford it, and thus capable of expanding its readership. Use of the word gazzetta begins to be recorded around 1570, but for many decades it seems to have been a term primarily belonging to spoken language, referring to news-sheets that lacked credibility. ${ }^{6}$ A gazzetta was typically

2 Quotations from the collection of avvisi preserved in Archivio di stato di Modena, Cancelleria ducale, avvisi e notizie dall'estero, bb. $1-3$.

3 See S.D.N.D. Pii PP. VConstitutio contra scribentes exemplantes, \& dictantes monita vulgo dicta gli auisi, \& ritorni (Rome: Antonio Blado, 1572) in Biblioteca Nazionale di Roma 13.F.23; Editto che predicatori non trattino nelle loro prediche de reporti \& avvisi (Rome: Paolo Blado, 1590), in Bibliothèque nationale de France, $\mathrm{E} 4720$.

4 See also 96, 272, 304, 471, 519, 678, and 724, below.

5 Infelise, Prima dei giornali, pp. 30-3; Brendan Dooley, The Social History of Skepticism. Experience and Doubt in Early Modern Europe (Baltimore: Johns Hopkins University Press, 1999), pp. 36-7.

6 For more on the word gazzetta see Ch. 10. 
handwritten, although printed gazzette (contemporary attestations of the term more commonly use the plural than the singular) began to appear from the early seventeenth century onwards. In the first decades of its use, gazzette could as easily refer to single-event, occasional newsletters as to parts of a regularly appearing series (which is what avviso more commonly refers to) but there is also evidence for the terms gazzetta and avviso being used interchangeably. The term gazzetta is conventionally supposed to derive from the name of a small-denomination Venetian coin in circulation in the sixteenth century and which came to stand metonymically for the newssheets whose purchase price it represented: late seventeenth- and eighteenth-century dictionaries and encyclopaedias offer this explanation and supply possible etymologies via Hebrew (Izgad, meaning messenger), or Persian (gazna-) via Greek ( $\gamma \dot{\alpha} \zeta \alpha)$, meaning treasure or treasure-house. ${ }^{7}$ This derivation is hard to verify, however; the earliest evidence we have for it in an Italian monolingual lexicon is from 1676. It is, however, mentioned in John Florio's 1598 Italian-English dictionary $A$ Worlde of Wordes and in Randle Cotgrave's Anglo-French dictionary of $1611 .{ }^{8}$ Early seventeenth-century dictionaries of Italian tend not to include the word, possibly because, as noted above, it was mainly a colloquial usage; it is notable that John Florio's 1598 Italian dictionary, which does include it, is more receptive to informal Italian than most contemporary monoglot dictionaries. ${ }^{9}$

The terms foglio (sheet) or foglietto (small sheet) are often used as synonyms of gazzetta or avviso and both were used for handwritten as well as printed matter. It was also common to use the expression foglio di avvisi to indicate a single sheet of news.

The term giornale (journal) appears only in the second half of the seventeenth century in the titles of literary and academic periodicals, probably in imitation of the French Journal des Sçavans (1665): Giornale de' letterati di Roma (1668), Giornale veneto de' letterati (1670), Giornale de' letterati d'Italia (1710). During the war against the Turks, at the end of the seventeenth century, and particularly after the siege of Vienna of 1683 , many military gazettes were printed in Italian cities with titles like Giornale dal campo cesareo a Buda (Journal of the Imperial encampment at Buda) or Giornale dell'armata veneta in

7 Ephraim Chambers, Cyclopcedia, or, An Universal Dictionary of Arts and Sciences (London, 1728), see under Gazette. Pierre Chantraine, Dictionnaire étymologique de la langue grecque, 2 vols. (Paris: Klincksieck, 1968-8o), p. 206.

8 John Florio, $A$ Worlde of Wordes (London 1598), p. 145; Randle Cotgrave, A Dictionarie of the French and English Tongues (London, 1611), sig. Ss3 ${ }^{\mathrm{r}}$.

9 On the dictionary of John Florio, see Michael Watt, The Italian Encounter with Tudor England: A Cultural Politics of Translation (Cambridge: Cambridge University Press, 2012), pp. 203-54. 
Levante (Journal of the Venetian Army in the Levant), and others more or less similar. The name did not indicate regular periodicity of publication, but rather the intention to provide a day-by-day account of what was happening in the war zones. The periodicity was effectively the consequence of protracted military actions that continued to stimulate interest because of their favorable outcome. Practical circumstances tied these military gazettes closely to the military events they reported; their publication ceased altogether in the winter months when military activity diminished. ${ }^{10}$

A relazione or relatione (relation), starting from the sixteenth century, was an occasional printed account of military or political events of particular importance. Generally it was a printed news pamphlet consisting of four pages in quarto or in octavo illustrating a specific fact or occurrence. Relazioni circulated widely and were frequently reprinted, often in different cities from the one in which they were first published. The expression Relatione de' successi (relations of events) was quite common, and is an obvious cognate for the Spanish Relaciones de sucesos. However, the Spanish term was not widely in use in the early modern period, and has been retroactively applied by historians.

The Mercurio, derived from the Latin title of the Mercurius Gallo-Belgicus first printed in Cologne in 1592 or the Mercurius Austrio-Bohemo-Germanicus of 1623 , was a printed series of books on contemporary historical events (like the German Messrelation). The most significant Italian example is the Mercurio ouero historia de' correnti tempi by Vittorio Siri, published in 15 volumes and over 20,000 pages between 1644 and 1682, and covering European history between 1640 and 1655 . Only later, in the eighteenth century, did the term mercurio imply periodical (monthly, biannual or annual) publication.

The terms in use for the professional newswriter and dealer in information varied from place to place on the Italian peninsula; between the sixteenth and seventeenth centuries a compiler of handwritten newsletters or gazettes was known as a menante in Rome, a reportista or scrittore di reporti in Venice, and a novellaro in Genoa. Novellante and novellista also occur, in the sense both of the newswriter and the more general meaning of a person interested in or enquirer after news.

In the last decades of the sixteenth century the use of the word gazzettiere (gazetteer) or gazzettante began to be recorded almost systematically, and with derogatory connotations. The earliest attempt at definition is that of John

10 Mario Infelise, 'The War, the News and the Curious: Military Gazettes in Italy', in The Politics of Information in Early Modern Europe, ed. Brendan Dooley and Sabrina Baron (London: Routledge, 2001), pp. 216-36. 
Florio, according to whom the gazzettiere was "an intelligencer or such as have daily occurrences". The Studio di reporti (office of reports) was the workplace of the reportista until the end of the eighteenth century; those in Venice were often located in the workshops of scribal copyists.

The term giornalista (journalist) appeared at the end of the seventeenth century to indicate exclusively the writer or the editor of a learned journalagain derived from the Parisian Journal des Sçavans. The word retained this meaning until the end of the following century, during which the clear distinction persisted between the journalist—a learned and worthy writer-and the gazetteer-a not very reliable writer of news.

\section{Germany}

In German, the key word in news and media terminology is Zeitung. The original term had a meaning similiar to 'news'. Zeitung derives from the Middle Low German word Tidunge, which meant some kind of event, incident or happening. The Low German roots of the word Zeitung are evident in the English tidings. The word begins to be reported from the region around Cologne about the beginning of the fourteenth century and was used to mean a message or an oral report of an event. In the late fifteenth and sixteenth centuries the word was used to describe a single piece of news (compare this with the secondary use of avviso in Italian).

The term Zeitung, in the sense of a printed newsletter, was used for the first time in 1502. It was also used to indicate handwritten newsletters analogous to Italian avvisi. In the late fifteenth and the early sixteenth century the so-called Newe Zeytungen developed in the German-speaking countries. The first example of a printed work answering this description was produced in Augsburg in 1482, though it was not published under the name of Zeitung. The Newe Zeytungen were for the most part non-serial and non-periodical printed works reporting single events such as battles, wonders, or reports of newly discovered lands. They usually had an elaborate title, which gave a summary of the contents, with a woodcut illustration below. They could take the form of single sheet prints or broadsheets, or pamphlets of twenty or more pages. Unlike avvisi and handwritten Zeitungen, the Newe Zeytungen mainly focused on reporting the sensational, since the printers who produced them had an eye to short-term financial gain.

In the early days of printed news, another commonly used term was Relation. In Middle High German, the word originally meant "to report on the fulfilling of an order" (given by some authority), or "eyewitness report". 
It derives from the Latin relatio, meaning "a bringing back, throwing back" and (secondarily) "a report". ${ }^{11}$ In 1583 Michael von Aytzing published his Relatio historica at the Frankfurt book fair. In doing so, he developed a new media genre, the so-called Messrelation. These were usually published twice a year at the large trade fairs (Messe) in Frankfurt and Leipzig and reported on the political, societal and military events of the past few months. The Messrelationen, originally intended as a kind of historiographical collection, were perhaps the first printed periodicals. They are often seen as the predecessors of periodical journals. ${ }^{12}$ To demonstrate their periodical character, the Relationen often bore the suffix continuatio.

Handwritten newsletters, such as the Fuggerzeitungen, also called themselves Zeitungen. Among the important differences between these and the printed Newe Zeytungen were an incipient periodicity, and the inclusion of reports on diverse topics in a single newsletter. They were the product of a cultural transfer from the Italian avvisi and dispacci in the sixteenth century and supplied more or less continuous coverage of events in the major European centres. $^{13}$

The earliest printed newspapers (also called Zeitungen), which first appeared in the German territories in the first decade of the seventeenth century, had much more in common with the manuscript newsletter tradition than with the Newe Zeytungen that had already been in print for over a hundred years. ${ }^{14}$ Along with Zeitung the foreign terms Avvisi and Relation remained in common use in Germany until the second half of the seventeenth century. The first printed weekly newspaper, founded by Johann Carolus 1605 in Strasbourg, was titled Relation aller Fürnemmen und gedenckwürdigen Historien, not using the word Zeitungen at all. The fungibility of the words Zeitung, Avviso and Relation are plainly apparent in the title of the second printed newspaper, printed in Wolfenbüttel in 1609 and called Avisa, Relation oder Zeitung, Was sich begeben und zugetragen hat. During the seventeenth century, the word Zeitung increasingly displaced the other terms used for

\footnotetext{
11 Wolfgang Pfeifer, et al., Etymologisches Wörterbuch des Deutschen (Berlin: Deutscher Taschenbuch Verlag, 1989), p. 1408.

12 Ulrich Rosseaux, 'Die Entstehung der Meßrelationen. Zur Entwicklung eines frühneuzeitlichen Nachrichtenmediums aus der Zeitgeschichtsschreibung des 16. Jahrhunderts', Historisches Jahrbuch, 124 (2004), S. 97-123.

13 Cornel Zwierlein, 'Fuggerzeitungen als Ergebnis von italienisch-deutschem Kulturtransfer 1552-1570', Quellen und Forschungen aus italienischen Archiven und Bibliotheken, 90 (2010), pp. 169-224.

14 Johannes Weber, 'Straßburg 1605. Die Geburt der Zeitung', Jahrbuch für Kommunikationsgeschichte, 7 (2005), S. 3-27.
} 
newspapers, so that the first German dictionaries and lexicons in the middle of the eighteenth century only record Zeitung. ${ }^{15}$ The titles of early newspapers also referred to their characteristics as periodicals, their mode of transmission, and their licensing by the authorities: see, for instance, the evolving names of the Frankfurter Postzeitung (founded in 1615), which was called Ordentliche Wochentliche Postzeitungen in 1626 and renamed Kayserliche ReichsPostzeitungen in 1706, indicating weekly periodicity, the means by which the news was transmitted, and the imperial authorisation.

During the seventeenth century many of the emerging German newspapers were named Zeitungen, with the result that the meaning of the word underwent a change. It was no longer used only for the reported message or the single piece of news itself, but came to stand metonymically for the whole developing medium of printed newspapers. In addition it was increasingly used in its singular form Zeitung, which no longer necessarily meant a single piece of news but a single newspaper. Zeitung kept its double meaning until the eighteenth century. German dictionaries from the late eighteenth century continued to refer to Zeitung in the sense of 'message' or 'report', but also noted that this usage was becoming obsolete. Nonetheless it remained in use until the late eighteenth century among authors including Schiller, Goethe and Lessing, though usually in a consciously archaic fashion.

In German, the word Journal describes a regularly published periodical and, in contradistinction to its usual meaning in French, it is not commonly used for daily newspapers. The first journals appeared during the second half of the seventeenth century and were called Journal, Magazin, Monatsschrift (monthly) or Sammlungen (collections). The current German word for journal, Zeitschrift, was not used until 1751 . During the seventeenth century, the journals had a wide variety of titles, including Monatsgespräche (monthly discussions / conversations), Monatsstücke (monthly pieces), Acta, or Anmerkungen (annotations). ${ }^{16}$

The word Gazette was borrowed from the Italian word gazzetta via the French gazette, and was used for periodical newspapers, mainly in Lower

\footnotetext{
15 E.g. Johann Heinrich Zedlers, Universallexikon (1732-54) and Johann Chrisoph Adelungs dictionary Grammatisch-kritisches Wörterbuch der Hochdeutschen Mundart (1774-86).

16 First German scientific journal: Acta Eruditorum (Leipzig 1682); first critical literature journal: Monatsgespräche (long title: Schertz- und ernsthaffter, vernünfftiger und einfältiger Gedancken über allerhand lustige und nützliche Bücher und Fragen erster Monath oder Januarius, in einem Gespräch von der Gesellschaft der Müßigen; Frankfurt and Leipzig 1688); first medical journals: Monatliche neu eröffnete Anmerckungen über alle Theile der Artzney-Kunst (Hamburg, 1679) and Collectanea medico-physica oder Holländisch JahrRegister, sonderbahrer Anmerckungen, die sowol in der Artzney-Kunst als Wissenschaft der Natur in gantz Europa vorgefallen (1680-82; Leipzig 1690).
} 
Saxony. Other names used for newspapers were Courante, Merkur and Diarium. Diarium was a fairly common title for daily newspapers, including the Wiener Zeitung, the oldest Austrian newspaper still in print, which was founded in 1703 under the name Wienerisches Diarium.

The usual word for the writer of news was Novellant (after the Italian novellista). During the seventeenth century, the main word was Zeitungsschreiber (writer of Zeitungen) and, less frequently, Zeitunger, which is more often used for editors of newspapers. As is the case with the corresponding terms in French and English, Journalist, which is common in modern German, was not used until the eighteenth century.

\section{Low Countries}

In the Low Countries a number of terms were in use that predated the newspaper but were subsequently used in newspapers and of newspapers. The most obvious of these is gazette, still used as an informal or dialect word for newspaper in general, but there are also tijding, advijs or advis, relation, and mercure or mercurius. All these terms were used to mean news, newsletter or news publication, and all were used at one time or another in the titles of periodical news publications. A term that seems to have been new in the early seventeenth century is courant, from which the modern standard Dutch term for a newspaper derives: krant.

That there was a certain fluidity and tentativeness to the terminology used is apparent from legal texts, which in attempting to be exhaustive have recourse to such lists of possible terms as "eenigerhande Fransche Couranten of Gazettes, 't zij onder de naem van Couranten, Gazettes, Gazette-Raisonnée, Nouvelles Choisies, Lardons, of wat andere Naem of Titul daer aen soude werden gegeven" ("any kind of French Corantos or Gazettes, whether under the name of Corantos, Gazettes, Gazette-Raisonnée, Nouvelles Choisies, Lardons, or any other Name or Title"). ${ }^{17}$

Gazettes: in 1601 the Neo-Stoic humanist Justus Lipsius first used the term gazettes in correspondence with his publisher, Joannes Moretus, to designate manuscript newsletters. This is the oldest use in Dutch that I have been able to identify. In 1615, a Dutch translation of Orlando Furioso used 'gaset' to mean a piece of news (not the most obvious translation of the Italian "fu detto", "was told", in Canto XII stanza 62, but one dictated by the exigencies of versification). It was included in the translator's appendix of 'poetic words' that

17 Proclamation of the States of Holland (21 February 1686). 
required a gloss, where it was explained that it meant "brieven die alle weken comen van Italien, van alle nieu tijdinghen" ("letters that come from Italy each week with all the news"). ${ }^{18}$ In 1618 the word appeared in the title of a book, a satirical collection of fictional news reports by the intelligencer and poet Richard Verstegan, indebted to Sir Thomas Overbury's Newes from Any Whence (1614). $\cdot{ }^{19}$ By the 1620 it was an established part of the language, with the city government of Kortrijk paying a Domyn Lathem for "port of gazettes and other services to the city" in 1620, and a draft decree (never issued) of the mid-1620s restricting the publication of "discours, gazettes, remonstrances, motifs ou avertissements de droit". ${ }^{20}$ The first Antwerp newspaper had no fixed title or masthead, but is usually referred to as the Nieuwe Tijdinghen, two words that are often part of the front page headline; occasionally, however, the word 'gazette' would appear on the front page, and the run in the British Library is catalogued as 'Antwerp Gazette.'21

By 1629 'gazette' was being used as a generic designation for printed newspapers, with a government order that Abraham Verhoeven, publisher of the Nieuwe Tijdinghen, cease from printing unlicensed 'gazettes.22 On 22 November 1635 Martin Binnart paid $£_{2} 5$ s. for the registration of his octroi (privilege, monopoly) "om die gasetten ende nijeuwe tijdingen te drucken" ("to print gazettes and new tidings"), giving legal protection to the newspaper that he launched under the title Den Ordinarissen Postilioen or Le Postillon Ordinaire. ${ }^{23}$ But the word seems also to have retained the older sense of weekly letters of news: a newspaper that began publication in Bruges in (or before) 1637 eked out a rather meagre subscription to foreign newswriting services with the contents of a weekly 'Brusselsche Gazette' which was almost certainly a manuscript serial.

18 Everard Siceram, Il Divino Ariosto, oft Orlando Furioso: hoogste voorbeelt van Oprecht Ridderschap, oock claren Spieghel van beleeftheijt voor alle welgeboorne vrouwen (Antwerp, 1615), sig. Rr2v.

19 R.V., Gazette van Nieuwe-Maren van de geheele wereldt. Ghemenght met oude waerheden (Antwerp, 1618).

20 Inventoried by Micheline Soenen in 1983 as ARB, Geheime Raad-Spaanse Periode, 1277/240. The archive has since been renumbered.

21 In 1620, for instance, an issue published on 16 October was titled Gazette Universele des Maents October, 'Universal Gazette of the Month of October', while in 1622, issue number 22, published on 16 February, was given the title De tweede Gazette des Maents Februarij 1622, 'The second Gazette of the Month of February 1622'.

22 Order in Council, 29 January 1629, Brussels, General State Archive, Officie Fiscal van de Raad van Brabant, liasse 177, dossier 1566.

23 ARB, Rekenkamer, 20805, fo. 192v. Unfortunately the licence itself, inventoried by Micheline Soenen in 1983, has since disappeared from the archive of the Privy Council. 
In the course of the later seventeenth and the eighteenth centuries, the word 'gazette' eventually found its way into the titles of such newspapers as the Gazette d'Amsterdam, Gazette de Leyde, Gazette de Liège and Gazette de Bruxelles.

Courant: another apparently new term in the early seventeenth century is courant, which produced the obsolete English coranto. In French it simply means 'running', sitting somewhere between courrier (a running messenger) and courant (signifying a current in water) - and it was used in sixteenthcentury Dutch both as a poetic loanword describing the motion of streams and beasts, and more mundanely to mean 'circulating', generally in collocation with money: 'courant geld', 'current money', meaning something like 'legal tender.' ${ }^{24}$ By extension it was used of the circulation of news, what would now be called 'current affairs'. It was the title of the first Dutch newspaper, Caspar van Hilten's Courante uyt Italien ende Duytschlandt, \&c., published from 1618 onwards. It was the title of two further Amsterdam newspapers of the 1640s, Joost Broerszoon's Ordinaris Dinghs-daeghs Courante (a mid-week supplement to the Saturday Tijdingen) and Mathijs van Meininga's Europische Saterdaegh Courant and Euroopsche Donderdaegs Courant.

The Dutch poet and magistrate Pieter Corneliszoon Hooft in his correspondence referred collectively to both Amsterdam newspapers, the Courante and its rival the Tijdingen, as loopmaeren (running reports), using the more everyday word for 'to run', 'lopen.'. 25

Tijdingen: one of the first Amsterdam newspapers, printed by Broer Janszoon in both Dutch and French, bore the titles Tijdingen uyt verscheyde Quartieren and Nouvelles de divers Quartiers, both of which would translate into English as "News from Various Quarters". As we have seen, the first Antwerp newspaper was often headlined Nieuwe Tijdinghen ("new tidings" or "fresh news"), while the first newspaper to be printed in Bruges bore the title Nieuwe Tydinghen uyt verscheyde gewesten (New Tidings from Various Regions), remarkably similar to Janszoon's Amsterdam title. The word is attested as early as the fifteenth century, when a chronicler wrote of "waiting for tidings from the Countess". ${ }^{26}$

24 J.A.N. Knuttel, Woordenboek der Nederlandsche Taal: Supplement, vol. 1 (The Hague etc.: Martinus Nijhoff, 1916), cols. 2156-8.

25 P.C. Hooft to Joost Baak, Muiden, 25 August 1631, in De briefwisseling van Pieter Corneliszoon Hooft, ed. H.W. van Tricht et al., vol. 2 (Culemborg: Tjeenk Willink, 1977), p. 233.

26 "daer hi lach ende wachte de tidinge die hem vander gravinnen comen soude", Bronnen van de geschiedenis der Nederlanden in de Middeleeuwen. Kronijk van Holland van een ongenoemden geestelijke (Gemeenlijk geheeten Kronijk van den clerc uten laghen landen bi der see) (Utrecht, 1867), p. 72, cited in E. Verwijs and J. Verdam, Middelnederlandsch Woordenboek, vol. 8 (The Hague, 1916), s.v. 'Tidinge'. 
Like 'Zeitung' in German, tijding was a common term in the titles of occasional news pamphlets in the sixteenth century, often in the collocation nieuwe tijding (new tidings, or fresh news), such as Goede nieuwe tijdinge, aengaende die victorie die de coninck van Enghelandt ghehadt heeft tegens die Schotten (Good new tiding concerning the victory obtained by the king of England against the Scots; Antwerp, 1544), or Nieuwe tijdinghe van alle het ghene dat geschiet is tusschen de Christenen ende de ongeloovighe Turcken, inde teghenwoordighe oorloghe van Malta (New tiding of all that has passed between the Christians and the infidel Turks, in the present war of Malta; Antwerp, 1565). It continued in this use well into the seventeenth century, as in the murder pamphlet Nieuwe tijdinge ende warachtighe beschrijvinge, van een man die sijn eygen vrou met vier kinders seer jammerlicken vergeven heeft (New tidings and true description of a man who piteously poisoned his own wife and four small children; published without place or date, in 1613 or 1614, "After the Copy Printed in Antwerp by Anthony de Ballo").

As Broer Janszoon's French title indicates, the French equivalent to tijdingen was nouvelles, and this occurred on seventeenth-century pamphlets in much the same way, such as Nouvelles trescertaines des grands presens faictz en Espaigne, au Prince d'Angleterre, de la part de sa Majesté Catholique que Dieu garde (Antwerp, 1623), Nouvelles de plusieurs endroicts de l'Europe (Brussels, 1635), and Nouvelles tirees de plusieurs lettres ([Douai], 1636). In the sixteenth century, however, the plural noun nouvelles was only very occasionally found in the title of a news report, which in French was far more likely to be labelled a relation. ${ }^{27}$

Relation: this was one of a number of terms frequently used in the titles of occasional news pamphlets to designate a substantial narrative account of a single event such as a battle, a siege, an execution, a wedding, or the concluding of a treaty. Others are discours and recit (with the Dutch equivalents relaes or relatie and verhael, and the Latin equivalent narratio), and description or beschryvinghe. They were often qualified with adjectives such as sommier (summary), cort (brief), veritable, vray, waerachtich (true) or zeker (certain), or some combination, producing such titles as Waerachtich verhael, Recit veritable, Discours veritable, Vray discours, Briefve description, Brevis narratio, Beschryvinghe oft cort verhael, Corte beschrijvinghe, Cort verhael, Sommier verhael, Certaine relation, and Cort ende waerachtich verhael. 'Relations' became

27 One such rare example is Certaines Nouvelles de la bonne \& heureuse victoire, que par l'ayde de Dieu, le Comte Charles de Mansfelt at obtenu en Honguerie, pres la ville de Strigonia (Brussels, 1595). 
the title of a newspaper in 1650, when the Courier véritable des Pays-Bas, printed in Brussels, was retitled Relations véritables.

A pamphlet or booklet giving a longer overview not of a single event but of a sequence of events might be called histoire or historie, verclaringhe (elucidation) or journael. So an account of the successive ceremonial welcomes and banquets of the new Queen of Spain as she travelled through Italy was entitled Waerachtige Historie vande Voyagien ende intreen geschiet door de Coninginne van Spagnien in Italien (Brussels, Rutger Velpius, 1599). Journaal, journal, or the Latin diarium, was used particularly for a retrospective day-by-day account of a siege or of a voyage, and sometimes doubled up as dagh-Journael (daily journal). This makes the use of 'journal' in the Low Countries quite distinct from its use in France, and explains the Dutch origins of 'journaliste. ${ }^{28}$ In Dutch, journaal is now the common term for a regularly scheduled television news broadcast.

Advijs: yet another word appearing as the name of a newspaper is advijsen, chosen by Jan van Hilten (Caspar's son) as the title for his Extraordinarie Advijsen op Donderdagh (Extraordinary Advices on Thursday), a mid-week supplement to his Courante, which came out on Saturdays. More generally, advijs or advis were used to mean a news report received from elsewhere, an avviso.

The term did have a different meaning in medical and legal circles. The newspaper publisher Martin Binnart had begun his career as a proofreader, and was also a lexicographer. He provided two entries for 'advis' in his dictionary, the first as "advice, counsel, opinion: Consilium, arbitrium, judicium"; the second a cross-reference to 'Advertentie', meaning warning or notification. ${ }^{29}$ It is in the first sense of 'expert opinion' or 'formal recommendation' that it appears in the title of one current-affairs pamphlet, Leon de Meyere's Advis pour la paix de la Belgique (Antwerp, 1598). In $163_{2}^{2}$ Nicolaas Breyghel, publisher of the first newspaper in Bruges, printed an 'Advertissement' which was an official instruction from the city council on plague precautions, adopted on the 'advice' of physicians.

Otherwise the meaning of 'expert opinion' is a distant connotation, if that, not the intended denotation. 'Advice' simply means 'report' in such common newspaper phrases as "Daer is eenen Post van Spaignien comen met nieuw Advis" ("A Post has come from Spain with new advice"), or "Men heeft advijs,

28 See n. 64, below.

29 "Advis / raedt / meyninge: Consilium, arbitrium, judicium"; "Advis / waerschouwinghe s. Advertentie"; "Advertentie / waerschouwinge: Monitio, praemonitio", Martin Binnart, Biglotton sive Dictionarium Teuto-Latinum (Antwerp, 1649). 
dat den Mansfelder eenen Aenslach hadde ghemaeckt" ("We have advice that the Mansfelder would have made an attempt"). ${ }^{30}$ It was already being used in this sense in the sixteenth century, for example in the phrase "Een Carveel, met advijs uyt Lisbonen, brenghende tydinge hoe dat ..." ("A caravel with advice from Lisbon, bringing tiding"). ${ }^{31}$ Very occasionally, it occurs as the verb "to advise', meaning to inform: "sullen metten naesten U.L. advizeren vant' succes" ("we will by the next advise you of the success"). ${ }^{32}$

Sometimes an Italianate (but not really Italian) form of the noun is used, for example "Wy hebben adviso, dat de Keyserinne metten Eertz-Hertoch Leopoldus te schepe van Regensborch den naesten wech naer Weenen soude verreysen" ("We have adviso, that the Empress has taken ship with Archduke Leopold in Regensburg to take the nearest route to Vienna"). ${ }^{33}$ Sometimes both 'adviso' and 'tiding' seem to be used simply as variations meaning 'news' or 'report', as in "Tot Genua is adviso comen van Barcelona dat den Prince Doria Galleyen 92. kisten met Realen van achten geladen hebben om naer Genua te comen. Voorders isser tijdinghe comen als dat de Cosaggen de Turcken inde swerte zee groote schade doen". ("Adviso has come to Genoa from Barcelona that the Galleys of Prince Doria have been laden with 92 chests of Reals of eight to sail to Genoa. Further the tiding is come that the Cossacks do great harm to the Turks in the Black Sea".) $)^{34}$

Post: Terms related to the posts include courier, postillon (post master), ordinaris or ordinaire (meaning regular posts), and extraordinaris or extraordinaire (meaning special postal messenger). All of these were used by transference of news that came by post, and the new coinage post-tijdingen (postal tidings) also conveys that meaning.

All came at one time or another to be used in the titles of newspapers: Van Hilten's Extraordinarie Advijsen op Donderdagh and Broerszoon's Ordinaris Dinghs-daeghs Courante in Amsterdam, Willem Verdussen's Extraordinaris Post-tijdinghe and Martin Binnart's Le Postillon ordinaire or Den Ordinarissen Postilioen in Antwerp, and in Brussels the Courier véritable des Pays-Bas.

Mercuries: The messenger of the gods also became a common term for news reports. Often a mercury was a news round-up covering a number of

$30 \quad$ News from Brussels, 7 May, Wekelijcke Tijdinge, 53 (1631). News from Cologne, Nieuwe Tijdinghen, 1 (5 January 1624).

Linschoten, Itinerario (1596), fo. $155^{\mathrm{v}}$, cited in C.H.A. Kruyskamp, Woordenboek der Nederlandsche Taal: Supplement, vol. 1 (The Hague, Leiden: Martinus Nijhoff, 1956), s.v. Advies (cols. 426-8). Further news from Calais, 1 February, Nieuwe Tijdinghen, 15 (10 February 1623).

33 News from Prague, 4 April, Nieuwe Tijdinghen, 51 (29 April 1623).

34 News from Rome in Nieuwe Tijdinghen, 102 (25 August 1623). 
months, or even years, in effect a work of contemporary history rather than a vehicle for communicating new information. This began with Mercurius Gallobelgicus of 1592, a six-monthly overview, primarily of news from France and the Low Countries, produced in Cologne by a Catholic exile from the Netherlands.

Adriaan van Meerbeeck gave his overview of five years of world affairs (1620-25) the title Neder-lantschen Mercurius oft Waerachtich verhael vande geschiedenissen van Nederlandt, ende oockvan Duytschlandt, Spaengien, Italien, Vranckrijck ende Turckijen (Netherlandish Mercury or True relation of the histories of the Netherlands, and also of Germany, Spain, Italy, France and Turkey; Brussels, 1625). In the second half of the seventeenth century there were a quarterly Europische mercurius and an annual Mercure hollandois published in Amsterdam, with another annual Hollandsche Mercurius in Haarlem. ${ }^{35}$ This general use of the term 'mercury' for monthly, quarterly, six-monthly or historical works did not prevent it also appearing as the title of a newspaper: the Wekelyksche Mercurius that appeared in The Hague in the later 1650s.

Placcart: when an official or public document was reprinted as an item of news, the title would often be the word appropriate to a document of that type, e.g. Sententie (sentence), Requeste Presentée au Roy (request), Lettres Patentes (letters patent), Articles accordez (articles of surrender), Manifest (manifesto), Edict, or Placcart. Unlike usage in France, in the Low Countries a placcaet or placcart, in both French and Dutch, was an edict or proclamation, affixed to church doors or posted up in other frequented places, as for example the Placcart du Roy Nostre Sire, Touchant le livre de l'Evesque Cornille Jansenius \& autres oeuvres \& livres specifiez en la Bulle de nostre St Pere le Pape Urbain VIII. du 8. de Mars 1642 (Brussels, 1651).

Other terms used for decrees were decret, proclamation or proclamatie, and ordonnance or ordonantie, and decrees of other governments could also be reprinted, or translated, if they were newsworthy in themselves. So when James VI and I decreed that goods seized from subjects of the King of Spain after the date of his succession were to be restituted to their former owners, this was "faithfully translated from the English into our Dutch speech" and printed in Antwerp, "after the copy printed in London by Robert Barker" under the title Proclamatie, Ofte ordonantie van de Coninlijcke Majesteyt van Engelant, waer in verclaert wert dat de Goederen die genomen zijn vande Ondersaten des Conincx van Spaengien sedert den 24. Aprilis lestleden: sullen werden gerestitueert aende eygenaers (Antwerp, 1603). This was not invariably the case. The official account of the rebellion of the Earl of Essex, printed in 
London as a proclamation, was reprinted in Brussels as a "true relation": Warachtich Verhael van tgene datter ghebeurt is in Ingelant binnen Londen (Brussels, 1601).

Pasquil and libel: scurrilous or defamatory publication, whether printed or scribal, might be known as a fameus libel or libel fameus (libelle fameux or libelle diffamatoire in French), or as a pasquil or pasquille (in French sometimes pasquin). The qualification 'famous' here means "touching a person's good name" (i.e. defamatory), rather than signifying that the libel itself had notoriety. At law the unqualified noun 'libel' meant simply a written plaint or claim, so defamatory libels were explicitly qualified as such. ${ }^{36}$ The standard Dutch work on criminal law, Joost de Damhoudere's Practycke ende handbouck in criminele zaeken, devoted a chapter to diffamatie by boucxkins (defamation by booklets)—sandwiched between chapters on tampering with merchants' ledgers and on tampering with dice-which used the phrase "fameuse libellen". ${ }^{37} \mathrm{~A}$ later chapter specified that injurien by ghescrifte ("injury by writing") could include "ghedichten, liedekins, boucxkins, refereinen, baladen, commedien, openbaere spelen" ("verses, songs, booklets, refrains, ballads, comedies, public plays") that detracted from somebody's name and fame. ${ }^{38}$ Thus Descartes's Epistola ad Dinetum and Epistola ad Voetium, two diatribes against the Utrecht professor Gijsbert Voetius, were described by the Utrecht authorities as "diffamatoire gheschriften of fameuse libellen" ("defamatory writings or famous libels"). ${ }^{39}$

A number of phrases used in newspapers provide reports of news circulated by word of mouth. These include "Men zeyt hier dat de Turcken van Barbarijen noch vijff Franssche schepen van Rowanen comende ghenomen heeft" ("It is said here that the Turks of Barbary have taken another five French ships coming from Rouen"); "Men verstaet oft wilt zegghen, dat zijne Keyserlijcke Majesteyt ghenadelijck soude verclaert hebben, dat hy gheen voorder ondersoeck oft Executie int Coninckrijck Bemen meer en sal doen doen" (It is understood or said, that his Imperial Majesty would have graciously declared that he will have no further investigation or execution carried out in the Kingdom of Bohemia"); "De sprake gaet hier voorseker als dat onse Coninginne

36 Joost de Damhoudere, Practijcke in civile saken (The Hague, 1626), cap. 99. First published as Praxis rerum civilium (Antwerp, 1566).

37 Damhoudere, Practycke ende handbouck in criminele zaeken (Leuven, 1555), cap. 125.

38 Damhoudere, Practycke ende handbouck in criminele zaeken, cap. 138.

39 In the pamphlet account Aengevangen Procedueren tot Wttrecht tegens Renatus des Cartes (Utrecht, [1643 or 1644]). On this controversy, see Theo Verbeek, ed., René Descartes et Martin Schoock: La Querelle d'Utrecht (Paris: Impressions nouvelles, 1988). 
die Godt beware swanger is" ("The speech goes here for certain that our Queen whom God preserve is pregnant"). ${ }^{40}$

Hooft's use of 'loopmaeren' (running reports) was touched on above. The first element, 'loop', is 'run'; the second, maere, was in Middle Dutch the main word for a piece of news. It is found in the title of the satirical Gazette van Nieuwe-Maren (Gazette of New Reports) printed in 1618. In Middle Dutch use 'mare' might be translated as 'renown', 'repute', or 'report', but towards the end of the seventeenth century it lost status to 'tiding', eventually coming to mean something indistinguishable from 'rumour'41 As late as 1667 the playwright Joost van den Vondel could use it simply to mean 'news' or 'report', 42 and it may retain this neutral meaning in a satirical prognostication for the year 1718 to the effect that 'mercurialists' (those keen to know the news) will eagerly look forward to the posts that often bring news that they do not like ("maeren ... die hun niet aen en staen").43

\section{France}

Political information circulating in the public sphere during the sixteenth century was broadly defined: witness the variety of its forms and genres, and the significant overlap between written forms and the sphere of oral transmission. The registres-Journaux (register-journals) published by the Usher of the Parlement of Paris, Pierre de l'Estoile (1546-1611), bear remarkable witness to this lexical variety, which is more precisely spelled out in the dictionaries of Estienne (1549), Nicot (1606), Cotgrave (1611), Richelet (1680), Furetière (169o), Gilles Ménage (1694), the Académie Française (1694), and others. ${ }^{44}$

40 News from Seville, 10 January, in Nieuwe Tijdinghen, 21 (25 February 1623). News from Prague, 4 April, in Nieuwe Tijdinghen, $5_{1}(29$ April 1623). News from Madrid, July, in Nieuwe Tijdinghen, 12 (25 August 1623).

41 For the earlier usage: Eelco Verwijs and Jacob Verdam, Middelnederlandsch Woordenboek, vol. 4 (The Hague: Martinus Nijhoff, 1899), s.v. Mare, citing, e.g., "Die coninghinne van Saba quam tote Salomoen, want si vernam van sire groter wijsheit mare" ("The Queen of Sheba came to Solomon, for she had heard report of his great wisdom").

42 "Genadighste mevrou, broght iemant quaede maeren?" in Zungchin, of Ondergang der Sineesche Heerschappye, act 4.

43 Nieuwen Gentschen Almanach voor het jaer ons heere Jesu Christi M.DCC.XVIII (Ghent, [1717]), s.v. Junius (unfoliated).

44 Robert Estienne, Dictionnaire françois-latin, autrement dict les mots françois, avec les manières d'user d'iceulx, tournez en latin (Paris, 1549); Aimar de Ranconnet, Thresor de la langue francoyse, tant ancienne que moderne (Paris, 1606); Cotgrave, Dictionarie of the 
The sixteenth century was predominantly characterised by occasional, as opposed to periodical news, which nevertheless achieved considerable impact in the public sphere thanks to the medium of print (regarded by some as a curiosity or a collector's item). News and pamphlets intermingled, borrowing from different literary genres and forms according to the type of information they contained. The two terms cited below, for instance, imply the clear identification of author or recipient:

- the depesche (despatch) denotes urgency, suggesting that the contents are important and concern affairs of state, and in particular the term implies express delivery, by means of an extraordinary courier.

- In the case of an advis, the information takes the form of a warning/ notification or an instruction, particularly in the political or military sphere. It is a piece of news which requires its recipient to take some sort of action.

Pamphlets made use of extremely diverse literary forms:

- Pasquils (lampoons), an import from Italy, were extremely widespread during the wars of religion, and usually directed against a well-known individual, whose conduct was denounced in the form of raillery.

- The more frankly insulting placcars (no direct English translation) are better understood as a mode and form of publication than a type of content. But the commonest use of the term, from the sixteenth to the end of the seventeenth century, refers to a full sheet of paper (or broadside) posted on walls or doors, often at night, attacking or criticising the government or individuals.

- Libelles most commonly occurs in collocation with défamatoire (defamatory); defamatory libels consisted of insults, reproaches or accusations, and constitute the most violent form of verbal attack against a person's honour or reputation.

- When the accusation's content is particularly brief, Pierre de l'Estoile refers to 'tiltres' qui courent (running titles).

- Memoires, by contrast, tend to be longer, and to follow closely upon the death of a well-known figure; the term refers not to autobiographical writing

French and English Tongues; Pierre Richelet, Dictionnaire françois, contenant les mots et les choses, plusieurs nouvelles remarques sur la langue françoise (Geneva, 1680); Antoine Furetière, Dictionaire universel, contenant généralement tous les mots françois tant vieux que modernes et les termes de toutes les sciences et des arts (La Haye, 1690); Gilles Ménage, Dictionnaire étymologique, ou Origines de la langue françoise, par M. Ménage. Nouvelle édition (Paris, 1694); Le Dictionnaire de l'Académie Françoise (Paris, 1694). 
but to texts made public in order to attack or to vindicate the reputation of the deceased. Forms related to memoires include épitaphes (short poems ending with an ingenious turn/epigram), tombeaux (funeral poems), as well as vers (verses) of all kinds; sonnets, poullets (love letters), quatrains, and éloges (panegyrics) in honour of the deceased. Posted up in the streets, they were politically consequential and (potentially) problematic, a public reflection of the tensions, rivalries and internal conflicts of society.

- Finally, there were also vaudevilles: these consisted of news put into song, satirical narratives of amusing adventures sung on the Pont-Neuf and in the streets, set to simple tunes.

This brief survey demonstrates the considerable overlap between oral and written forms. In its material forms, news was mostly put up in places of political significance such as the Hôtel de Ville (city hall), Parliament, or on the walls or doors of the houses of this or that prominent person. It was also cried abroad in Parisian streets and at crossroads before spreading through the streets. The text very quickly breaks the bonds of its original medium and is translated into the sphere of orality. (The verb commonly used for the oral telling or retelling of news, conter, has overtones of fantastical as well as factual narration; news becomes subject to all manner of transformations and travesties.) The transition to the oral form denotes a decline towards less dignified genres, appropriate to the masses; a change reflected in the terminology, as news takes the form of médisances (missayings), false or insulting language used towards a person, or quolibets (bad puns, or double entendres, considered false, trivial, and wretched).

Movement is essential to the description of news. When addressed to a particular recipient, news vient (comes) or arrive (arrives) by normal means, i.e. through the normal infrastructures of communication. When addressed to the undifferentiated audience of the streets, however, it is variously said to be publiée à son de trompe (trumpeted), affichée (posted up), placardée (placarded) in certain parts of town, or semée (sown), divulguée partout (spread everywhere), jetée (thrown about) then ramassée (gathered up), courant partout (running everywhere) through a town which is abreuvée with it (awash). It carries with it the possibility of disorder; it consists of grands or mauvais bruits (great or evil noises), which might be deliberately threatening and in danger of tipping over into sedition, or 'murmurs', which suggest the as yet muffled and varied complaints of the disaffected. The murmurings of the people constitute an early warning of possible sedition which prudence requires be nipped in the bud. Control of the news was a matter of public order. 
This brief overview of the terminology in use in the sixteenth century demonstrates that the news, which was at once fragile, dubious, and threatening, had indisputable subversive potential; the reception of news in the public sphere shows it to be an excellent indicator of tensions running through society.

The advent of periodicity in the seventeenth century, closely linked to the improvement of roads and the postal network, can be traced in the vocabulary used by Théophraste Renaudot, founder of the Gazette. In 1611, Cotgrave reported the origin of 'Gazette' as a word for a small-denomination Venetian coin, which gave its name to the short bulletins of news Venice put out each month and sent throughout Christendom. ${ }^{45}$ The term is far from flattering; in the seventeenth century, it also denotes the causeuse (chatterbox), the woman who reports all the goings-on of her neighbourhood outside it - itself a kind of transgression against secrecy, and one related to the familiar notion that on political subjects, parler sûr (speaking of) is as much forbidden as parler contre (speaking against).

According to Furetière, by the end of the seventeenth century it was mainly the common people who showed the most avid interest in the news purveyed by the Gazette (whereas the usual readership in its early years consisted of urban elites). News is the offspring of the post and the printing press; carried by courriers (messengers who worked a particular road and carried several packets of letters in a satchel slung over their horse's crupper) in letters and correspondences (both terms implying an exchange, a reciprocal relationship).

The gazettes establish an ordering principle, a geographical and chronological classification of news, as well as hierarchies: Renaudot's Gazette aims to become "the newspaper of kings and potentates of the Earth"; and frequently the authorities "make [such-and-such] known", or "order that [such-and-such] be published". News follows the hierarchies of a holistic society and trickles down to the lower reaches of the population: this was enough to give the Gazette the reputation of an official publication (although this account of it becomes considerably more problematic upon closer analysis). ${ }^{46}$

During the seventeenth century, many specialist news publications came into being, with new formal features and a variety of names to suit their contents, geographical origin, frequency of publication, literary genre, style, and so on: ${ }^{47}$

\footnotetext{
45 See, n. 8, above; and Ch. 10, below.

46 Gazette (Paris, 1631), p. 4; Stéphane Haffemayer, L'information dans la France du XVII siècle. La Gazette de Renaudot de 1647 à 1661 (Paris: Honoré Champion, 2002).

47 Jean Sgard, ed., Dictionnaire des Journaux (1600-1789), 2 vols. (Paris: Universitas, 1991).
} 
- first among these are the mercures, which Furetière presents as 'books', the periodicity of which may be annual (as in the case of the Mercure François) or monthly (the Mercure Galant). In both cases, their function is "to announce something new".

- Courriers (see above) and relations appear more frequently. (Relations are narratives of adventures, battles, or events: these accounts are expected to be faithful and exact.)

- In the provinces affiches (posters) appear, derived from the placards used to put up proclamations in public spaces; they are utilitarian in character and their formalisation in the eighteenth century made them the forerunner of the provincial press. They gave significant space to classified advertisements.

- The journal. Etymologically speaking this should be a daily report on events, but within the context of the Ancien Régime's system of information indicates literary or natural-philosophical content (political content was reserved for the mercuries and gazettes).

The periodical's title would be qualified by an adjective specifying its thematic or geographical remit, or even its ethos: as for instance général, vrai (true), fidèle (faithful), universel, celeste, désintéressé (impartial), souterrain (underground), historique, savant (expert), politique, and so forth. The title would also come to indicate periodicity: "ordinaire", derived from "the courier who rides post and carries letters" (Richelet, 1680), while "extraordinaire" denoted not so much an occasional publication as "an express courier, charged with some urgent business" (Furetière, 1690). The Gazette published one extraordinary issue per week, on average, in the middle of the seventeenth century. A further proof of the success of the periodical press was the development, especially from the middle of the seventeenth century onwards, of satirical forms which aimed to amuse more than to inform; in these instances the periodical might be described as babillard (babbling), burlesque, extravagant, poétique, gallant, héroï-comique (mock-heroic), plaisant (jesting), and so forth.

From the lack of any professional designation for early modern newswriters, who for the most part wrote anonymously, and sometimes under multiple identities, we may conclude that it was not an activity to boast of, at least until the end of the eighteenth century, by which time it was possible for newswriters to claim to be illuminating the public. ${ }^{48}$ In the meantime, gazetier and

48 Stéphane Haffemayer, 'Un relais de l'innovation en province: le Journal de Normandie de Jean-Baptiste Milcent à la veille de la Révolution', in Un siècle de journalisme culturel en Normandie et dans d'autres provinces: $1785-1885$, ed. Catriona Seth and Eric Wauters (Mont-Saint-Aignan: Publications des universités de Rouen et du Havre, 2011), pp. 25-40. 
nouvelliste were unflattering terms, considered largely disreputable through most of the Ancien Régime, as we might expect from a genre long held in contempt by men of letters, and little sampled by historians right down to the present.

\section{Spain}

In Spain, between the fifteenth and the eighteenth centuries, the most common name for cheap printed items containing news was relación, which literally meant an account or narration; a term close in meaning to the English "news pamphlet". However, this assertion must be qualified in several ways:

- Relación, a derivation from relatar (the act of telling), was used to identify the informative purpose of the pamphlet. ${ }^{49}$ With this name, readers could easily distinguish them from other printed products in the market, such as oraciones (speeches) or coplas (ballads). But relaciones did not necessarily involve actual news: a case in point were the relaciones about Catholic saints, giving accounts of their lives from the moment of their birth to their final days, or the detailed narratives of a complete festivity at Court, taking up to some hundred pages. This is the reason why we can find heterogeneous printed products entitled relación when searching in Spanish early modern catalogues.

- Not even half of the Spanish news pamphlets had a header containing the word relación. Instead, we find nuevas, an old word for the modern "noticia", used in the same sense as the English "news"; correo, similar to the English "courant" or "current"; and many other words used on title pages to help readers recognise them as informative papers. Moreover, hundreds of news pamphlets had titles that simply summarised the events described. The typography was sufficient to make their clients distinguish them from other kinds of printed pamphlets.

- Spanish scholars speak of relaciones de sucesos, that is, "pamphlets about events", but this is a recent coinage and the actual pamphlets hardly ever

49 In the Middle Ages a 'relación' was an account of important events sent to the monarch, and its rhetorical pattern contributed to the birth of the informative early modern genre. Pedro Cátedra García, 'En los orígenes de las epístolas de relación', in Las «relaciones de sucesos» en España (1500-1750), ed. Maria Cruz García de Enterría, Augustin Redondo, Henry Ettinghausen and Víctor Infantes (Paris, Alcalá de Henares: Publications de la Sorbonne, 1996), pp. 33-64. 
make use of this term. ${ }^{50}$ Again, this is a label used broadly, sometimes to identify different kinds of printed works. Scholarly misunderstandings and debates are common on this terminological issue. ${ }^{51}$

- The Spanish term is derived from Latin, and derivations of the same word are mostly found in Italian, French, Portuguese and German news market as we have already seen. This no doubt speaks of the strong connection between Mediterranean and German journalism under the Habsburg rule.

With these caveats, we nonetheless find that throughout the early modern period the word relación most commonly refers to a brief printed productusually a single-sheet pamphlet, consisting of four pages-recounting a piece of news at length. This is usually a news item of an international or political character, but it can also be national and local news, and it can be presented in verse or prose.

If relación is the name of the editorial product, aviso (one $v$ in Spanish) is the name of the single informative unit— the "news item" in English, or noticia in contemporary Spanish. We already know the Italian origin of the word: avviso, plural avvisi. ${ }^{52}$ But, as they were short in length, news pamphlets usually collected several avisos, so we commonly find avisos—plural—in the titles. The first appearance of the term avisos in the title of an existing Spanish news pamphlet is Carta venida de Pavia, de diversos y varios avisos de Constantinopla de la muerte de Selimo y dela creacion y coronacion de Armorad emperador ottomanno de los turchos. Con algunos avisos dela enfermedad que tuvo, y en siendo curado los presentes que mando enviar al santissimo sepulchro de nuestro señor Jesu Christo en Hierusalem. Con otras nueuas de la guerra entre el y el Sophi y de la armada suya, en Constantinopla a los 26 de abril de 1575 (Barcelona, 1575). Some years later the term appears at the start of a title, now signifying the informative genre: Avisos de la China y Japon del fin del año de 1587, recebidos en octubre de 88, sacados de las cartas de los padres de la compañia de Jesus que andan en aquellas partes (Madrid, 1589). A title which perfectly describes the genre as a gathering of heterogeneous news items is Avisos

5o The term sucesos—-meaning simply 'events' in modern Spanish—carried positive overtones in early modern Spanish, close to the English 'success'. This way, the tag 'relaciones de sucesos' used in Spanish bibliography, emphasises the political or propagandistic nature underlying these printed newspapers.

51 Víctor Infantes de Miguel, ‘¿Qué es una relación?: divagaciones varias sobre una sola divagación', in Las «relaciones de sucesos» en España, ed. Cruz García de Enterría et al., pp. 203-16.

52 Jean-Pierre Étienvre, 'Entre relación y carta: los avisos', in Las «relaciones de sucesos» en España, ed. Cruz García de Enterría et al., pp. 111-22. 
de diversas partes. En que se da relacion de muchas cosas acontecidas en los meses de junio hasta el de septiembre del presente año de 1597 (Barcelona, 1597).

As can be noticed, avisos was at first most commonly used to refer to news items from remote lands, such as the Ottoman or the Chinese empires; but it finally evolved to describe a single piece of news received from any sort of source, such as in the news pamphlet Avisos de Londres de XIX de março de mil y seiscientos y uno de la muerte del conde de Essex (Sevilla, [1601?]).

The avisos travelled by post and were collected into handwritten or printed papers of several items each. For that reason, the most common name in Spanish for the resulting product is relación de avisos - that is, a narrative piece which selects and relates a number of news items received between two dates. For example: Relacion de avisos de todo lo que ha sucedido en Roma, Napoles, Venecia, Genova, Sicilia, Francia, Alemania, Inglaterra, Malta y otras partes, desde seis de enero deste año 1618 embiada desde la dicha ciudad de Roma a esta de Sevilla a un personage grave (Sevilla, 1618). ${ }^{53}$

But all these were occasional news pamphlets; the first appearance of serial avisos in Spain, as far as we know, is the series published in Seville by the printer Rodrigo de Cabrera on the Christian struggles against the Turks in Hungary, from 1595 to 1600 . At least thirty pamphlets have been found belonging to this serial. Thus the start of the Spanish news market can be dated as far back as the latest decades of the sixteenth century.

However, there was not in early modern Spanish news writing an expression meaning "weekly news" or "wekelijcke tydinghen". Even if news pamphlets were frequently produced as series and were identifiable by the use of a few repeated words in the titles of all numbers-such as victoria, refriega, famosathey were sold simply as relaciones, without any actual reference to a regular lapse of time. This confirms that periodicity was a difficult achievement for Spanish printers.

The same non-systematic usage characterised the term gazeta or gaceta (the latter being the modern spelling). The word possibly derived from (see Ch. 10) a Venetian coin which came to be used across much of Europe. The first printed products entitled gazeta appeared in Spain around 1618 - the year in which the outbreak of the Thirty Years War vastly increased both the demand for and circulation of international news across Europe. We know of two Spanish news pamphlets from this period that use the term in their titles: a single issue of a Gazeta

53 We can relate this title to those appearing in the first German gazettes, such as the famous Avisa Relation oder Zeitung. Was sich begeben vnd zugetragen hat in Deutsch: und Welschland Spannien Niederlandt Engellandt Franckreich Ungern Osterreich Schweden Polen unnd in allen Provintzen in Ost: unnd West Jndien etc (Wolfenbüttel, 1609). 
Romana printed in Seville, 1618; and three remaining issues of a Gazeta de Roma published in Valencia in 1619. But, in both cases, these pamphlets belong to an extended series whose issues rarely had the term gazeta in their titles. Even if Spanish printers had discovered serial journalism, they had not conceived the commercial possibilities of using the word gazeta in the header of a pamphlet.

It was two decades later, during the early $1640 s$, that a serial Gazeta was published in Barcelona by the printer Jaume Romeu. This appeared during the period of French political dominion of Catalonia and the texts were translated from Renaudot's French Gazette. It was also in the 1640 s that a Gazeta was published in Lisbon, during the Restoration War (discussed below). Romeu's Gazeta had the status of an official newspaper within Catalonia. The first official gazette for the whole Habsburg kingdom of Spain was Gazeta Nueva (later the Gazeta de Madrid), published from 1661 onwards; however, initially this was a monthly, only in 1667 becoming a weekly.

The writer of relaciones was simply referred to as an escritor, or writer; the writer of gazetas was a gacetero or gacetillero, but these words are seldom found in the Spanish pamphlets of the time, and where they are used they have pejorative connotations. In the context of modern journalism these words are obsolete. The most common names for papers in Spanish today are diarios and periódicos. The first one, meaning "daily", was used in imitation of French during eighteenth century, because it served to translate the French term journal-as in Journal des Savants. Thus diaristas were intellectuals who wrote in cultural or scientific journals. The first actual daily newspaper in Spain was the Diario Noticioso, edited by Francisco Mariano Nipho from $175^{8}$ onwards.

Other words commonly used to describe the occupation of news writing were papelista (the person who makes papeles, or papers) or jornalista (copied from the French journaliste). We can also find significant terms like escritor público, or public writer. It could be concluded that, even if journalism was not yet regarded as a profession, in Spain like in the rest of Europe the writing of newspapers was undertaken by literate people who deserved for the first time some kind of recognition.

Periódico is an abbreviation from the current phrase "papeles periódicos", and has been the most common name for newspapers since the nineteenth century. Correspondingly, the word in use in Spanish for journalist is periodista. In the same manner, the current Spanish word for journalism, periodismo, is as recent as the nineteenth century. This is to say that there was not a Spanish word for journalism during the early modern period, despite the thousands of news pamphlets and gazettes that were published and the "news fever" that, we know for sure, affected Spanish men and women as well as their 
contemporary European neighbors. This fact, besides being an interesting socio-historical issue, implies the lack of a proper cataloguing of ancient papers, which does not help scholars researching in libraries or archives.

\section{England}

News in English is both grammatically singular and plural. It combines the senses of a series of things that are new, and a discrete, complex, and semantically resonant field of information, customs and expectations. We can begin to trace this semantic field through news-related terms in seventeenth-century English dictionaries and glossaries. Hence in the glossary appended to Henry Preston's Brief directions for true-spelling (1673), news is defined as "report of things".54

In Thomas Blount's more substantial Glossographia (1656) we find the word news used in the a series of related entries:

Annunciate ("to declare unto, to bring news or a message");

Diurnal ("a Day-book, or Register of every days business, news, or action"); Gazet ("Venetian Coyn scarce worth our farthing; Also a Bill of news or short relation of the general occurrences of the time, forged most commonly at Venice, and thence dispersed every moneth into most parts of Christendom");

Hawkers ("Those people which go up and down the streets crying Newsbooks, and selling them by retail");

Mercury ("a swift messenger, or for a book of news, because such books are (as it were) the messengers of the newes");

Prenuncious ("that first brings tidings, that goes afore and tells news"; this seems to be from Thomas Thomas' Dictionarium, 1587);

Prodrome ("the fore-runner or news-bringer of another mans coming"); Scandalum Magnatum ("false news, or horrible and false Messages"). ${ }^{55}$

One of the reasons Blount compiled his dictionary, he tells his readers, was because of the proliferation of words in many books, even (perhaps especially)

54 Henry Preston, Brief Directions for True-Spelling (London, 1673), p. 50.

55 I have used 'Lexicons of Early Modern English' (<leme.library.utoronto.ca/>) and correlated results with Early English Books Online (various portals). Blount's book is organised alphabetically. Note that the entry for 'Gazet' is lifted word-for-word from Cotgrave's $A$ Dictionarie of the French and English Tongues (London, 1611). 
books of news: "In every Mercurius, Coranto, Gazet, or Diurnal, I met with Camizado's, Pallizado's, Lantspezado's, Brigades, Squadrons, Curasiers, Bonmine, Halts, Iuncta's, Paroles \&c" ${ }^{56}$ While lamenting the excesses of print was a common hobby among writers, there is much evidence to corroborate Blount's picture of verbal expansion.

Among the early uses of the words gazette and coranto in English is a 1621 printed sermon that draws attention to the transnational aspect of news. The preacher complains about false rumours believed by one who "suffered himselfe to be so grosly guld with every fabulous Gazette, and idle Corante that posts betwixt England and Doway". ${ }^{57}$ The timing is significant: Henry King preached very shortly after the appearance of the first English corantos. In John Florio's Italian dictionary (Queen Anna's new world of words, 1611), Nuóua is translated as "a news, a new report. Also new."; while in Randle Cotgrave's French dictionary of the same year, Nouvelle is translated as "a novell, newes; tidings; an (unexpected) message; a strange report; a discourse, or tale unheard of before". The English lexicon of news is always sensitive to its transnational, foreign nature, perhaps because many writers wished to imply that it was, like immoderate fashions, essentially a foreign business.

Elisha Coles' English Dictionary of 1676 was less engaged with exploring networks of cultural associations than Blount's dictionary. Coles instead focussed on 'difficult terms' or 'hard words'; he was also very open to borrowed words. Here, in addition to many of the above terms, we find "news" also used to gloss:

\author{
Albricias ("reward of good news", borrowed from Spanish), ${ }^{58}$ \\ Bode ("Messenger; also foretel; also to ask news"), \\ Controver ("he that invents false news"), \\ Coranto ("a French running dance, also a News-book"), \\ Courant ("a news-book"), \\ Evangelium ("the Gospel, good news"), and, oddly,
}

Hermotimus ("a Lydian whose soul was wont to wander far from his body and return with foreign news ...")

Coles deploys the word report more frequently, associating it, for example, with bruit, decant, famigeration ("a divulging, reporting abroad", from the

\footnotetext{
$5^{6}$ Blount, Glossographia (London, 1656), sig. A2v. The bold font is blackletter in the original.

Henry King, A Sermon Preached at Pauls Crosse, the 25. of November (London, 1621), pp. 58-9.

$5^{8}$ This is a Spanish word with an Arab etymology; it is also found in Portuguese, alvíssaras.
} 
Latin, literally to carry fame - not widely used), infamy, narration, nunciature ("a report or message"), relatist. Some of these words do not seem to have been in common use, and are included for completeness or the kind of entertainment that dictionary-makers relish. On the other hand, many of these words were in common use long before their appearance in these dictionaries, so little is to be inferred from the dates of publication. The dictionaries attest to the ambivalence in which news was held in seventeenth century England, and, indirectly, to widespread interest in it: news is both the report of things, and also a common appetite. They also attest to how useful the word "news" was for defining other terms.

Dictionaries can be slow. Also in common use, though not appearing in these lists, were other, related terms that defined the semantic field of news: intelligence, intelligencer, information, journal, diary, newsbook, tidings, newsmonger. In fact seventeenth-century English news serials seldom used the word "news" in titles, at least after the 1620s: they preferred occurrences, transactions, proceedings, passages, affairs, relations, intelligence, informations, and, of course, mercury and gazette. These are only the most common, which reveals some of the richness of English news culture; some of the proliferation may have arisen particularly because of the need for product differentiation in a crowded marketplace during the 1640s. The omission of the word "news" specifically from titles is partly because of the ambivalence surrounding it: the word had been partly discredited in the early-seventeenth century, being used for sensational pamphlets, whereas the editors of the 1640 s newsbooks wished to emphasise that these were, initially at least, serious records of matters of fact. ${ }^{59}$ It is important to recognise that attitudes were not simply negative, or negative in an uncomplicated way: the idea of news was taken seriously, and participants in news culture thought hard about the nature of communication, evidence and reliability (after all the Royal Society turned to the periodical as a means of publishing its experiments). More significantly, the language of news had come to accommodate the competing values of news as fact and news as interpretation - a theme on which news editors were thinking quite hard. Witnessing this, the word news was being used as a verb by the mid-seventeenth century, as in "to news it about".60

Perhaps the most important English term for news in the middle of the seventeenth century is the collocation diurnal occurrences. This was the term

\footnotetext{
59 Newsbooks I reserve for the quarto weekly news serials of the 1640s, as distinguished from the foreign-news, near-weekly translated corantos of the 1620s; a distinction made by many contemporaries.

60

OED: news, $v$.
} 
given to the weekly manuscripts of parliamentary news that circulated first in the late 1620 s and then from 1640 onwards. These manuscripts are essential to the development of written news communication in Britain, and why the archipelago is anomalous in the broader context of Europe. Avvisi did circulate in Britain, and the corantos of the 1620 s borrowed the form then prevailing in the Netherlands. However, the division between domestic and overseas news was in some ways even sharper there than elsewhere, and norms of secrecy and the so-called 'privileges' of parliament meant that printed news was limited in its contents-limited to translations of foreign news, and to non- or indirectly-political news. In manuscript the story was different, however. Scribally published weekly accounts of parliamentary proceedings intermittently provided detailed domestic political news. These manuscripts were called 'Diurnal occurrences or heads of proceedings in parliament' and variations of the same. Because they were reporting on parliament, the organisation of the news was, unlike corantos, temporal rather than geographical: they contained daily accounts of proceedings. Hence diurnal referred to the daily frequency of news and not to publication. Here we can see the necessity of employing a term not commonly in use elsewhere in Europe in order to reflect local conditions. The first truly periodical printed news in Britain-after the irregular publication of corantos, which were in any case banned for most of the 1630s-appeared when these manuscripts, and not avvisi, were printed. It was these, and not corantos, that survived government controls and continued over future centuries. Hence the earliest London printed periodicals of news looked very different from their European counterparts, with domestic news, their own system of organisation, a unique set of cultural references. Later news publications would, crucially, mix the two forms of diurnal occurrences and avvisi. The development of news in Britain fitted into a European system, but it was also highly idiosyncratic or exceptional. ${ }^{61}$

A central characteristic of the culture of news in Britain, and one that has been largely overlooked, is the way its words and forms rely upon local, particular and transient significations and associations. This is not to suggest that it is provincial or exceptional — it was thoroughly connected to Europe, though the emergence of periodical news there followed a different pattern to other European regions. Rather, English meanings existed in microclimates. Its

61 Joad Raymond, The Invention of the Newspaper: English Newsbooks, 1641-1649 (1996; Oxford: Clarendon Press, 2005), pp. 80-126, the manuscripts discussed at 100-12. For these reasons Britain cannot be simply collapsed into a generalised European system, as Wolfgang Behringer does, without attention to any evidence. See 'Communications Revolutions: A Historiographical Concept', German History, 24 (2006), pp. 333-74, at 350. 
words and forms changed rapidly, and the very particular applications of the word can be lost in translation, and are lost over time. They are, however, recoverable.

This can be seen in the interrelations between the words news, intelligence, and information in 1640 s London newsbooks. ${ }^{62}$ The latter two were more mediated: 'news' was the matter, while 'intelligence' was 'news' that had been interpreted and digested for the reader. 'Intelligence' revealed the expertise of the editor and was what distinguished between competing news publications. This corresponds to the meaning of intelligencer, that is to say a spy, communicating select or secret knowledge; but this kind of intelligencer was a public intelligencer rather than a secret one. Intelligence was, then, superior to unmediated news; this process of interpretation and mediation improved the news. This should be contrasted with opinion, which in the seventeenth century was pejorative; it was mere opinion. Information, meanwhile, referred to the editorial matter that guided the interpretation of news; more mediated than intelligence, it was news put to use; it 'informed' the judgement of readers. Hence opinion was not intelligenced or informed. There is a spectrum of increasing activeness in the words news, intelligence, information. The terms were articulated in The Scotish Dove, a weekly London newsbook, in July 1645:

It may be some will tell me, (as they have) that I digresse from the way of intelligence, \& c. to them I answer; That I digresse not from the way of information, which I have ever propounded to my selfe to mix with my intelligence; information to cleare the judgement, is better then intelligence to please the fancie; and by such information the evill causes may be removed, from whence flow evill effects and sad intelligences.... ${ }^{63}$

Which is to say, the civil war. These are relatively positive terms. The editor's role (journalist would be an anachronism) is to mediate between political actors and the public. ${ }^{64}$ The keywords are being used with striking and cerebral

62 This argument is made in Raymond, Invention of the Newspaper, pp. 158-63; it is presented in a broader context in Raymond, 'Exporting Impartiality', in The Emergence of Impartiality: Towards a Prehistory of Objectivity, ed. Anita Traninger and Kathryn Murphy (Leiden: Brill, 2014 [2013]), pp. 141-67.

63 Scotish Dove, 92 (25 July 1645), p. 723.

64 According to the OED the word journalist first appears in 1693, in The humours, and conversations of the town, in the phrase "Epistle-Writer, or Jurnalists, Mercurists", signifying someone who writes a journal-this is distinct from the modern sense of the word and the modern role of the journalist, someone who gathers news. Marion Brétéché observes that journaliste appears in the early eighteenth century, in French-language political 
precision, however, and the lexicon is one the editor thought his readers would grasp, despite the fact that he, like his fellow editors, was engaged in the production of popular print culture. This usage may be specific to London in the mid $1640 s$, or even to a particular community. It does, however, run consistently through the uses of these words in London-based print in the 1640s, and therefore has some claim to be a significant element in the meaning of these words.

Similar distinctions underpin the words mercuries, mercury-women, and hawkers. While often treated as near-synonyms, or as distinguished by gender, they in fact represent different roles within the book trade. Mercuries and hawkers were itinerant street vendors (though mercury could also mean a publication or a bringer of news; and a hawker might sell other items in addition to news, such as pamphlets and ribbons and buttons), whereas mercury-women, from the early 1640 , were wholesale distributors who carried books from printers. Blount writes in 1656 :

Hawkers, Are certain deceitful fellows, that go from place to place buying and selling Brass, Pewter, and other Merchandize, that ought to be uttered in open Market. The Appellation seems to grow from their uncertain wandering, like those that with Hawks seek their Game where they can finde it.... Those people which go up and down the streets crying News-books, and selling them by retail, are also called Hawkers; and the women that sell them by whole sale from the Press, are called Mercury-women. ${ }^{65}$

The term mercury-women is gendered, though it does not designate a female mercury but a distinct role-and this reveals something of the nature of the language of news. The news culture of early-modern England went through periods when it was fast-changing and fungible, and we need to be aware of the tensions between slowly developing institutions and economic structures that shape the press, and a swiftly shifting culture.

The corantos of the 1620 s preferred such terms as courant, relation, weekly news, avisoes and advices to describe news publications. The active vocabulary rapidly expanded in the 1640 s to include intelligence, intelligencer, information, journal, diary, newsbook, tidings, occurrences, transactions, proceedings,

journals originating in the Netherlands. Les Compagnons de Mercure: Journalisme et politique dans l'Europe de Louis XIV (Paris: Champ Vallon, 2015), pp. 13-14.

65 See Blount, Glossographia, under Hawkers. Also the anonymous The Downefall of Temporizing Poets (London, 1641), though the distinction is not so clearly articulated there. See also B.E. A New Dictionary (London, 1699) under 'Mercury-women': "Whole-sale News-sellers, who Retail to the Hawkers". Also OED: Mercury, n., 4b, which is not clear. 
passages, affairs, relations, intelligence, informations, mercury and gazette, plus other terms that were form-specific, such as letter or dialogue (a common form of occasional news pamphlet). After the monarchy took control of the press in 1660 and established a (sometimes interrupted or broken) monopoly, the term gazette also achieved a de facto near-monopoly: it was the main term for a serial news publication. At the same time, however, a word like popularity (the deliberate courting of public support) moved from purely negative connotations to more neutral ones, and courant and newsbook lost the faint condescension they had carried with them. Entries in Coles' 1676 dictionary for coranto, courant, diurnal, gazette and Mercury all pointed to "news-book" as a definition; while John Kersey's English Dictionary of 1702 simply defined news-book as a "paper containing public news". In this respect at least the necessary vocabulary had narrowed and stabilised as news publications became less suspect and more embedded in the culture.

For all of their interest in news culture, the English were happy to modifysometimes quite freely —an international news vocabulary, and contributed little of their own; they innovated through absorbing the foreign. And some words seemed too foreign: Traiano Boccalini's De' ragguagli di Parnaso was a popular book, first translated (as The New-Found Politicke) in 1626, and reprinted or published in different translations in 1648 (a fragment), 1656, 1669, 1674, 1704, 1705, 1727 and beyond. The thoroughly clever satire of English civilwar news culture, The Great Assises Holden in Parnassus (London, 1645), appropriated Boccalini's form. But the word ragguaglio, which contemporaries translated as 'advices' or 'advertisements', was hard on the English tongue, and did not spread.

\section{Portugal}

The modern Portuguese word for news is notícia, a word that existed in the early modern vocabulary and that could be used to mean an account of a hitherto unknown event. But other words were used to signify news, including nova, novidade and also — once again — aviso (with a single $v$, as in Spanish). Whereas the connotations of nova and novidade were quite narrowly associated with the action of receiving and sharing news, notícia and aviso had a more complex semantics. As in other Romance languages, the noun aviso and the verb avisar had a late medieval meaning pertaining to the circulation of news ('ter aviso', to take notice) but also possessed a variety of older senses, of earlier medieval origin, concerned with giving and receiving instructions, opinions or warnings of a moral or political nature. The constellation of 
meanings clustered around news can be looked up in Raphael Bluteau's early eighteenth century dictionary, the most complete lexicographical compilation printed in early modern Portugal. ${ }^{66}$

We can infer from Bluteau's dictionary entries semantic distinctions between the senses of the word notícia on the one hand and the words nova and novidade on the other. The former was clearly associated with conhecimento (knowledge) or something that vem ao conhecimento (comes to knowledge), with no exclusive nor primary relation to actuality. Bluteau enumerates different kinds of notícias based on their philosophical and intellectual nature (news derived from science, from opinion, from faith, natural or acquired news, etc.), regardless of their relation to the form of their transmission. This same sense of notícias as a form of knowledge is present in other Portuguese authors preceding Bluteau, like Jerónimo Cardoso or Bento Pereira. ${ }^{67}$ As for the words nova and novidade, they were clearly associated with recent events or with things that were deemed modern. For Bluteau, nova describes any event that is new and is the subject of divulgation. But he also establishes an association between novas and rumores (rumours), defined as news lacking an identified author or origin. This linking of news and rumour is one of the root causes of the frequent dismissal of news, newsprint and agents of news by scholars. Hence, the gazeta is described by Bluteau as a papel (printed paper) containing news from abroad-there is no reference to or implication of periodicity, which in his dictionary remains largely an astronomical notion. His dictionary disqualifies Gazetas from serious consideration by a quotation from 1650 describing them as being of "little importance", along with manifestos (political proclamations). As in other European languages the vocabulary to describe news writers carried pejorative connotations, reflecting weak professional autonomy and authorial dignity. Though not mentioned in printed dictionaries, the word gazeteiro was used in letters and newsletters.

As suggested above, a reconstitution of the sense of the lexicon of news must include not only the relations between the layers of meaning recorded in the dictionaries, but also the uses of words in a variety of sources, from correspondences to legal texts, which incorporate new words faster than dictionaries do. The words used to describe news in ordinary practice were more various than those we find in dictionaries. And the circulation of news was accompanied by fundamental qualifiers, of which two of the most important, well into

66 Raphael Bluteau, Vocabulario Portuguez e Latino, 8 vols. (Coimbra, 1712-28).

67 Dictionarium Latinolusitanicum (Coimbra, 1570). Thesouro da lingua Portuguesa (Lisbon, 1647). 
the late eighteenth century, drew a distinction between particular (particular or private) and público (public) news. This partly coincided with the distinction between printed and handwritten news, but not entirely. For instance, both oral and handwritten news made echo of public vozes que correm (running voices), and boatos (rumours).

Turning now to specific objects in circulation, it is necessary to underline the fact that in sixteenth and seventeenth century Portugal no specific word definitively identified a handwritten sheet of news. The word aviso could be used in the sense of a news item-one of the senses of the Italian word avviso-but it did not become a synonym for a circulating object. Cartas de novas was the most used expression, describing both the object (the letter) and its content (the news).

As for printed news, seventeenth century royal decrees establishing censorship mechanism or prohibiting specific titles, offer one system of classification. A royal letter from 1627 mentions relações de novas gerais (relations of general news) and the need to submit them to strict pre-publication censorship. ${ }^{68}$ It was not, however, until several decades later that the word gazeta, borrowed from the French, was used as the name of the first monthly periodical in Portuguese (1641-7).

Another relevant source to identify the lexicon of news are the different petitions made by printers and booksellers to the competent higher royal court, the Desembargo do Paço, in order to obtain privileges to print and sell pamphlets of news. In 1642 the privilege to print novas do reino (news of the kingdom, i.e. domestic news) in a gazette included also a reference to relações (which Bluteau describes as a "narrative of something that happened") translated from French. 69

The name relação was generally given to non-periodical, translated, printed pamphlets during the seventeenth century; and these could appear in serial form, though not strictly periodicals. The word gazeta was also used to signify current news coming from abroad. It can be found in poems and satirical parodies of news, both handwritten and printed, pointing to the development of a community of readers of foreign gazettes even though there was no Portuguese counterpart before 1715 .

68 Royal letter, 26 Jan. 1627, in José Justino Andrade e Silva, ed., Collecção Chronologica da Legislação Portugueza (Lisbon, 1855). <www.iuslusitaniae.fcsh.unl.pt/verlivro.php?id _parte $=96 \&$ \&id_obra $=63 \&$ pagina $=964>[3 / 3 / 16]$.

69 Privilege to João Franco Barreto to translate and print French relations and gazettes, Lisbon, Nacional Archives (Torre do Tombo), Chancelaria de D. João IV, livro 15, fos. $3 \mathrm{v}, 2 \mathrm{v}$. 
A growing diversity of names given to printed papers of news, periodical and otherwise, emerges between in royal privileges awarded in the first half of the eighteenth century. These names corresponded to the different types of printed papers in circulation, translated or otherwise, and over which petitioners sought to obtain a monopoly. Alongside gazetas, eighteenth-century printing privileges mention notícias and papéis de notícias or mercúrios universais (universal mercuries) called estado do mundo (state of the world), and also, after 1742, suplementos (extraordinaries, or supplements to the gazette), relações de batalhas (accounts of battles) and epanáforas (relations, accounts; see below). The title mercúrio is of course important, for it was also part of the European landscape of circulating titles; and there also existed a seventeenthcentury Portuguese precedent, the monthly paper published by the secretary of state António de Sousa de Macedo between 1663 and 1667. In the years after 1742 the Mercúrios Históricos e Políticos were printed in Lisbon, also monthly, translated from the French periodical edited in The Hague, then into Spanish and finally into Portuguese. Of these different titles, only gazetas (with their suplementos) and mercúrios were associated with printed periodicals. Nonetheless, in legal texts explicit reference to periodicity does not occur until $175^{2}$ - when the expression gazeta regular (regular gazette) is used.

At the start of the eighteenth century one important handwritten newsletter circulating in Lisbon was the Gazeta em forma de carta (gazette in the form of letter). The word folheto (small sheet), of Italian origin, was increasingly used to indicate handwritten newsletters, generally meaning a separate of handwritten news sent by post. Eighteenth-century handwritten periodicals, edited in Lisbon by the count of Ericeira, and in Santarém, were called diários (a day-by-day account of current events, in a use equivalent to "journal" in Dutch or English language, mentioned above), folhetos and also mercúrios.

Influenced by the circulation of printed sheets of news and infected by the terms in use throughout Europe, we find examples of late-seventeenth-century diplomatic correspondence which describe handwritten separates of news as gazetas de mão (gazettes by hand), probably also an expression of French origin ("gazettes à la main", as opposed to "gazette de bouche"). ${ }^{70}$ This is an important indicator of the migration and fungibility of the term 'gazette', since in the course of this chapter we have traced its movement from Venice to Lisbon via Paris over more than a century; in its progress along this inverted v-shape, its

70 See the letter from the Portuguese ambassador in Paris, José da Cunha Brochado, to an unknown correspondant, 15 June 1698: Cartas (Lisbon: Sá da Costa, 1944), p. 31. 
use also shifted to the point where what had been a normal attribute for a gazette - that it was handwritten - has to be clarified as an exception in the Portuguese lexicon of news.

\section{European Conclusions}

We can see contrasting fortunes in several words: avviso and aviso spread across Europe to signify both a piece of news and the medium of communication. Gazzetta spread too, though whereas in Italy it could signify both written and printed news as it moved to Germany, France and the Iberian peninsula it shifted its significance to mean printed news, and became the pre-eminent term for a printed periodical. The textures of words can be subtle and nuanced: at least from 1631, gazzetta always implied regularity in a way that avviso did not.

Other words were more idiosyncratic and particular. There are the very local and specific resonances of information and intelligence in English news culture. And compare this with epanáfora: in eighteenth-century Portuguese it is used synonymously with "relação", and the dictionaries define it as both a rhetorical term (synonymous with anaphora) and a relato (story, relation), relating both to its Greek etymology. The editor of the Gazeta de Lisboa, José Freire Montarroio Mascarenhas, published a pamphlet in 1735 entitled Epanaphora belica, followed by several occasional news pamphlets on Portuguese military success in India between 1746 and 1752 with titles beginning Epanaphora indica ... Others subsequently used the term with this significance. It implied repetition, and so could suggest the bringing together of multiple items, either as a series or within a single pamphlet. Yet it has this significance in no other European vernacular. Could this idiosyncratic usage simply originate in the title of Francisco Manuel de Melo's Epanaphoras de Varia Historia Portugueza (Anaphoras of Various Portuguese History; Lisbon, 1660), a historiographical work in five discrete stories? Mascarenhas might have been borrowing not only the notion of gathered stories but also the cultural prestige of this widely-celebrated history. If so, it is one of the more extreme examples of local cultures adapting transnational vocabularies, and finding space for an eccentric word within the existing multilingual lexicon.

The translators who lived and worked in Europe's entrepôts, mediating between merchants, diplomats, travellers, and soldiers, played a crucial role in establishing and maintaining the news networks of early modern Europe. The mobility of lexicons of news was essential to their labour, and to that of 
the scribes and publishers who gathered and dispersed news in its various forms. In the semantic and geographical shifting of the words for news we can see the evidence of them borrowing and improvising in order to minimise the obstacles that language differences could present. We can also see evidence of tensions between these practical labourers in news communication and more localised readers, satirists, and especially governments who sought to define the news and its technologies in laws intended to confine its subversive potential. 